Discussion Paper No. 108

\title{
A LOGIT ANALYSIS OF ELECTRONIC BANKING IN NEW ZEALAND
}

\author{
Christopher Gan ${ }^{1}$ \\ Mike Clemes ${ }^{2}$ \\ Visit Limsombunchai ${ }^{3}$ \\ and \\ Amy Weng
}

March 2006 
1 Corresponding Author: Associate Professor, Commerce Division, PO Box 84, Lincoln University, Canterbury, New Zealand, Tel: 64-3-325-2811, Fax: 64-3-325-3847, Email: Ganc1@Lincoln.ac.nz

2 Senior Lecturer, Commerce Division, PO Box 84, Lincoln University, Canterbury, New Zealand, Tel: 64-3-325-2811, Fax: 64-3-325-3847, Email: Clemes@Lincoln.ac.nz

3 and 4 Graduate Student, Commerce Division, PO Box 84,Lincoln University, Canterbury, New Zealand, Tel: 64-3-325-2811,Fax: 64-3-325-3847, Email: limsomv2@lincoln.ac.nz and wengy2@lincoln.ac.nz 
Commerce Division

Discussion Paper No. 108

\title{
A LOGIT ANALYSIS OF ELECTRONIC BANKING IN NEW ZEALAND
}

\author{
Christopher Gan \\ Mike Clemes \\ Visit Limsombunchai \\ and \\ Amy Weng
}

March 2006
Commerce Division
PO Box 84
Lincoln University
CANTERBURY

Telephone No: (64) (3) 3252811 extn 8155

Fax No: (64) (3) 3253847

E-mail: ganc1@lincoln.ac.nz

ISSN 1174-5045

ISBN 1-877176-85-0 


\begin{abstract}
Financial institutions have been adopting internet banking since the mid 90 s, predominantly due to lower operating costs associated with internet banking, and pressure from non-banks interested in entering the internet banking market. In addition, customers utilizing internet banking facilities are increasing, as the cost savings on transactions over the internet are substantial (Mols, 1998; Sathye, 1999). Internet banking enables speedy transactions, access, time and money savings through providing free paper, and complete and up-to-date transactions. The competitive landscape of financial institutions is shifting as internet banking is no longer a competitive advantage but a competitive necessity for banks
\end{abstract}

The literature has featured numerous published research papers, articles and books addressing a wide range of issues relating to electronic banking (see Pyun, Scruggs and Nam, 2002; Li, 2002; Mols, 1999). However, there is little empirical research on the effect of electronic channels on consumer's buying behaviour (Hendrikse and Christiaanse, 2000) or banking channel preferences in New Zealand

The purpose of this research is to examine consumers' decision-making between electronic banking and non-electronic banking in New Zealand. The research uses the consumer decision making process (or paradigm) to identify factors that consumers use when deciding between electronic banking and non-electronic banking. These factors include service quality dimensions, perceived risk factors, user input factors, price factors, service product characteristics, and individual factors. The demographic variables include age, gender, marital status, ethnic background, educational qualification, employment, income, and area of residence.

Keywords: Electronic Banking, Service Quality, Information Technology, Internet banking, Consumer Choice, Risk

Paper Category: Research Paper 


\section{Contents}

List of Figures

List of Tables

1. INTRODUCTION 1

2. BACKGROUND 2

2.1 The Consumer Decision - Making Process 2

2.1.1 Service Quality Dimensions 3

2.1.2 Perceived Risk Factors $\quad 5$

2.1.3 User Input Factors $\quad 6$

2.1.4 Price Factors $\quad 7$

$\begin{array}{lll}2.1 .5 & \text { Service Product Characteristics } & 7\end{array}$

$\begin{array}{lll}2.1 .6 & \text { Individual Factors } & 7\end{array}$

3. METHODOLOGY, THEORETICAL MODEL AND DATA 8

3.1 Qualitative Choice Model of Electronic Banking 8

$\begin{array}{lll}3.2 & \text { Data } & 13\end{array}$

4. $\quad$ EMPIRICAL ANALYSIS 14

5. CONCLUSIONS 16

$\begin{array}{ll}\text { REFERENCES } & 17\end{array}$ 


\section{List of Figures}

1. Consumer Decision-Making Process Model

\section{List of Tables}

1. Profile of Respondents 22

2. The Reliability Test for the Measures of Electronic Banking 24

3. Estimation Results 25 


\section{Introduction}

The banking industry is constantly responding to changes in customer preferences and needs; increasing competition from non-banks, changes in demographic and social trends, information technologies advances, channel strategies, and government deregulations of the financial service sector (Giannakoudi, 1999; Byers and Lederer, 2001). Success or failure of many retail banks is dependent upon the capabilities of management to anticipate and react to such changes in the financial marketplace. In the search for sustainable competitive advantages in the competitive and technological financial service industry, banks have recognized the importance to differentiate themselves from other financial institutions through distribution channels. This has resulted in banks developing, and utilizing new alternative distribution channels to reach their customers (see Daniel, 1999; Thornton and White, 2001).

Furthermore, information technological developments in the banking industry have speed up communication and transactions for customers (Giannakoudi, 1999). The information technology revolution in the banking industry distribution channels began in the early 1970s, with the introduction of the credit card, the Automatic Teller Machine (ATM) and the ATM networks. This was followed by telephone banking, cable television banking in the 1980s, and the progress of Personal Computer (PC) banking in the late 1980s and in the early 1990s (Giannakoudi, 1999). Information technology enabled electronic channels to perform many banking functions that would traditionally be carried out over the counter (Giannakoudi, 1999). According to Gerdes and Walton (2002), the rise of electronic payments media such as debit and credit cards has caused the value of checks paid in the United States to fall to from about \$49billion in 1995 to about \$42 billion in 2002. Furthermore, paper checks are gradually being supplement with electronic images, permitting greater storage capacity, reducing costs and improving customer services (Rose and Hudgins, 2005).

The evolution of electronic banking, such as internet banking from e-commerce, has altered the nature of personal-customer banking relationships and has many advantages over traditional banking delivery channels. This includes an increased customer base, cost savings, mass customisation and product innovation, marketing and communications, development of non-core businesses and the offering of services regardless of geographic area and time (Giannakoudi, 1999). Internet banking is expected to become a widely adopted method for disseminating information and exchanges in the near future.

Similar to its international counterparts, the adoption of electronic banking such as internet banking is growing in New Zealand. The first bank to offer internet banking service was the Auckland Savings Bank (ASB) in 1996, followed by the ASB subsidiary, BankDirect, which was the first and the only virtual bank without physical branches (Parker, 1999). This was followed by National Bank of New 
Zealand (NBNZ) and Bank of New Zealand in late 1999. During the last quarter of 2001, there were approximately 480,000 regular internet users utilizing internet banking facilities to conduct their banking transactions. This reflects a 54 percent growth from 170,000 users during the same quarter of 2000 (Taylor, 2002). It is predicted that the usage of internet banking in New Zealand will continue to grow in the near future, as customer support for internet banking is mounting. Internet users adversity to internet banking has fallen from 32 percent in 1998 to 11 percent at the end of 2001, and of the 250,000 internet users whom have not yet adopted Internet banking, 65 percent indicate they are willing to adopt this new banking channel (Taylor, 2002). In addition, the decreasing charges of internet service providers in New Zealand are further enhancing the utilization of internet banking.

The literature has featured numerous published research papers, articles and books addressing a wide range of issues relating to electronic banking (see Pyun, Scruggs and Nam, 2002; Li, 2002; Mols, 1999). However, there is little empirical research on the effect of electronic channels on consumer's buying behaviour (Hendrikse and Christiaanse, 2000) or banking channel preferences in New Zealand. The purpose of this research is to examine consumers' decision-making between electronic banking and non-electronic banking in New Zealand. The research uses the consumer decision making process to identify factors that consumers use when deciding between electronic banking and non-electronic banking. These factors include service quality factors, individual factors, price factors, risk factors, service product factors, and user input factors.

\section{Background}

\subsection{The Consumer Decision-Making Process}

The consumer decision-making process pioneered by Dewey (1910) in examining consumer purchasing behaviour toward goods and services involves a five-stage decision process. This includes problem recognition, search, and evaluation of alternatives, choice, and outcome. Dewey's decisionmaking framework viewed the consumer as an information processor, manipulating information through the various stages of the decision process, and suggested that the process, at least theoretically, applied to the full range of consumer decisions.

Furthermore Dewey's framework was adopted and extended by Engel, Kollat and Blackwell (1973) and Block and Roering (1976). Block and Roering (1976) suggested that consumers may regress to a preceding stage of the problem solving process at any point in order to redefine the initial problem, search for new information, or to re-evaluate potential problem solutions. The consumer may also discontinue the problem solving process at any stage due to changes in their desired or actual state. Furthermore, the intervention of environmental factors such as income, cultural, family, social and physical factors also constraint consumers from advancing to the first four stages in the consumer 
decision-making process: the problem recognition stage, the search stage, the evaluation of alternative stage, and the choice stage.

Analogous to Dewey's (1910) consumer decision-making process for goods, Zeithaml and Bitner (2003) suggested the decision-making process could be applied to services. The five stages of the consumer decision-making process operationalized by Zeithaml and Bitner (2003) were; need recognition, information search, evaluation of alternatives, purchases and consumption, and postpurchase evaluation (see Figure 1). Zeithaml and Bitner (2003) imply that in purchasing services, these five stages do not occur in a linear sequence as they usually do in the purchase of goods. In addition, there are a number of generalizations which have been postulated to differentiate some aspects of consumer behaviour in services from goods (see Zeithaml and Bitner, 2003).

The variables that consumers' use to evaluate service alternatives come in many forms. The number of variables involved, as well as the way they influence consumers' evaluation of alternatives varies according to the type of situation (Loudon and Bitta, 1993). The literature suggests the following variables are relevant to consumers' decision-making between electronic banking and non-electronic banking service quality factors, individual factors, price factors, risk factors, service product factors, user input factors and demographic characteristics (see Figure 1).

\subsubsection{Service Quality Dimensions}

SERVQUAL as a measurement instrument, and the five SERVQUAL dimensions identified by Parasuraman, Zeithaml and Berry $(1985 ; 1988 ; 1991)$, have been used in the banking industry (Zhu, Wymer and Chen, 2002). SERVQUAL has been acknowledged and widely used in assessing banking service quality. For example, Llosa, Chandon and Orsingher (1998) investigated the applicability of SERVQUAL in the banking industry, and Levesque and McDougall (1996) adapted a selection of service quality items from Parasuraman, Zeithaml and Berry's (1988) SERVQUAL measurement in order to gain insights into service quality from the bank customers' perspective and to better understand the determinants of customer satisfaction.

Jun and Cai (2001) identified bank customers' perceptions of service quality dimensions using quantitative techniques. The authors' conceptualised internet banking service quality based on three quality perspectives; banking service product quality, customer service quality and online systems quality. Bank service product quality was primarily related to product variety and the diverse features of the service products. Customer service quality was related to the differences between customers' expectations of service provider's performance and their evaluation of the services they received. Online system quality was associated with the quality that the customer perceived when they where the end-users of an information system. The authors also identified seventeen underlying dimensions of electronic banking service quality including; product variety/diversity features, reliability, responsiveness, competence, courtesy, credibility, access, communication, understanding the 
customer, collaboration, continuous improvement, contents, accuracy, ease of use, timelines, aesthetics, and security.

Avkiran (1994) developed six dimensions to measure branch banking customers' perceived service quality for a major Australian trading bank. Using principal component factor analysis, the author reduced the six dimensions into four dimensions, staff conduct, credibility, communication, and access to teller services. Sureshchandar, Rajendran and Kamalanabhan (2001) used factor analysis to identify five major service quality dimensions for banking. These include core service or service product, human element of service delivery, systematisation of the service delivery, tangibles of service, and social responsibility. Core service or service product referred to the features of a service. The human element of service delivery quality dimension related to the reliability, responsiveness, assurance empathy, moments of truth, critical incident and the recovery aspects that fall under the domain of the human element in the service delivery. The systematisation of the service delivery dimension pertained to the process, procedures, systems and technology that would create a seamless service. The tangibles of service dimension related to physical facility, equipment, personnel, and communication materials. Social responsibility service concerns with the elements that send signals towards improving a bank's image and goodwill, and subsequently have an impact on customers' overall evaluation of service quality.

Perceived service quality is defined as the degree and direction of the difference between a customer's perceptions and expectation (Zeithaml, Parasuraman and Berry, 1990). The service quality dimensions, as identified in this research, are represented as a bank customer's overall impression of their electronic banking service experience. In the context of electronic banking, the literature review identified three service quality dimensions; reliability, assurance and responsiveness.

Sathye (1999) and Polatoglu and Ekin (2001) found that the reliability dimension was an important determinant for consumers who used electronic banking. Furthermore, Sathye (1999), Liao and Cheung (2002) found that reliability was positively related to the use of electronic banking. They concluded that the more secure that consumer perceived electronic banking to be; the more likely they were to use electronic banking.

Previous research have shown that assurance dimension of electronic banking is important to the consumers' utilization of electronic banking (see Polatoglu and Ekin, 2001; Liao and Cheung, 2002). Furthermore, Gerrard and Cunningham (2003) found that the assurance dimension (such as the confidentiality aspect that is associated with electronic banking) was positively related to the use of electronic banking. 
In the case of the responsiveness dimension, Karjaluoto, Mattila and Pento (2002) demonstrated that electronic banking users believed that electronic banking responded faster to their needs than other traditional modes of banking, for example, the speed of bill payment via the internet. In addition, Polatoglu and Ekin (2001) identified instant feedback, quick transactions and easy access, as important attributes in electronic banking. Furthermore, Liao and Cheung (2002) and Gerrard and Cunningham (2003) found that the transaction speed (the perceived speed of response from electronic banking) and the fast access to electronic banking accounts were important attributes for consumers that used electronic banking. Thus the following relationship is hypothesised:

A higher level of performance on the service quality dimensions is positively related to consumers' positive choice of electronic banking.

\subsubsection{Perceived Risk Factors}

Consumers perceive greater risks when buying services than tangible goods (Clow, Baack and Fofliasso, 1998). Zeithaml (1981) perceived services as riskier than products because services are intangible, non-standardised, and often sold without guarantees or warrantees. Consumers can rarely return a service to the service provider since they have already consumed it, and some services are so technical or specialised that consumers possess neither the knowledge nor the experience to evaluate whether they are satisfied, even after they have consumed the service (Zeithaml, 1981).

Perceived risk is considered an important risk attribute that impacts on the consumer decision-making process when buying a product or consuming some services (Mitchell, 1998). Electronic banking is a technology-enabled channel and consumers' perceive the use of electronic banking as a risky decision because technology-enabled services exhibit pervasive technological, unfamiliar and ambiguous stimuli (Davidow, 1986). Therefore, when consumers decide to use electronic banking, they are exposed to uncertainties such as the availability, the compatibility, and the performance of the complementary electronic banking channels (Sarin, Sego and Chanvarasuth, 2003).

Ho and $\mathrm{Ng}$ (1994) and Lockett and Littler (1997) empirically support that the use of electronic banking involves risk. Ho and $\mathrm{Ng}$ (1994) suggested that consumers perceived an existence of risk was present with the use of electronic banking. Similarly, Lockett and Littler (1997) identified risk as an important characteristic of electronic banking. These include financial risk, performance risk, physical risk, social risk and psychological risk.

Financial risk represents the financial loss in using electronic banking, as consumers may perceive that reversing a transaction, stopping a payment after discovering a mistake, or a refund may not be possible. Performance risk in electronic banking is less satisfying than non-electronic banking, as consumer may perceive that electronic banking cannot be used to complete a transaction when needed due to the denial of access to their account. Physical risk in electronic banking refers to potential 
injury when personal information is accessed by a third party. Social risk refers to the older generation who may disapprove of the use of electronic banking due to their perception that non-electronic banking is personal and friendly. Psychological risk represents consumer perceptions that the use of electronic banking would lower the self-image of themselves, or have a negative effect on their perceived image from other consumers. Time risk in electronic banking implies that it takes more time to complete a banking transaction than a non-electronic banking transaction. Thus the following relationship is hypothesised:

Higher perceived risk is negatively related to consumers' positive choice of electronic banking.

\subsubsection{User Input Factors}

Pervious studies have identified that user input factors are a function of control, enjoyment and intention to use (Ng and Palmer, 1999). Control could be described as the amount of effort and involvement required by consumers in electronic banking. Enjoyment is the perceived playfulness and intrinsic value that consumers experience from the utilization of electronic banking. The intention to use is described as the level of resistance to change, which is associated with consumers' intention to change from non-electronic banking to electronic banking.

Mantel (2000) concluded that the control attribute was one of the most important aspects that customers were concerned with when they used electronic banking. Similarly, Liao and Cheung (2002) identified that user control, such as the amount of control or contribution involved in electronic banking transactions, was a significant determinant for consumers' decision to use electronic banking. Similarly, Bateson (1985) identified that consumers chose to use a technology-based channels in the delivery of a service, not because of the monetary incentives, but because they perceived a stronger sense of control as a result of a self-service option (Bateson, 1985). Control in electronic banking relates to the consumers' perceived involvement, or sense of control, if they utilize electronic banking (Mantel, 2000).

Gerrard and Cunningham (2003) identified that consumers who were more financially innovative had a higher probability of adopting electronic banking than less financially innovative consumers.

Similarly, Sathye (1999) found that even when consumers were aware of the availability of electronic banking, some consumers might still not utilize this type of banking due to consumers' low intention to use electronic banking. Empirical evidence from Sathye's (1999) and Gerrard and Cunningham's (2003) studies suggested consumers' intention to use electronic banking was positively influenced the use of electronic banking. Thus the following relationships are hypothesised:

A higher user input factors is positively related to consumers' positive choice of electronic banking. 


\subsubsection{Price Factors}

Price factors suggest that perceived relative economic advantages will motivate consumers to use electronic banking (Sathye, 1999). For example, consumers using electronic banking could lower the fixed and variable costs that are associated with the banking process, due to reductions in personal error and labour cost savings.

The Wallis Report (1997) indicated that for consumers to use technologies, the price to use technologies needed to be reasonable when compared to alternatives. Sathye (1999) argued that, in the context of internet banking, two kinds of price were accounted for; the normal costs associated with internet activities, and the bank costs and charges.

Polatoglu and Ekin's (2001) study identified that users of electronic banking were significantly satisfied with the cost saving factor through electronic banking. However, researches have also suggested that consumers perceive electronic banking as inexpensive and that it does not offer any extra cost benefits (Karjaluoto, Mattila and Pento, 2002; Gerrard and Cunningham, 2003). Despite these conflicting findings, Sathye (1999) identified that the costs associated with electronic banking, such as the cost of electronic banking activities and bank charges, had a negative effect on electronic banking adoption. Thus the following relationship is hypothesised:

A higher price paid by consumers will negatively impact on consumers' positive choice of electronic banking.

\subsubsection{Service Product Characteristics}

In general, additional specific service features, service specifications, targets of a service, and the core service comprise service product characteristics. The service product characteristics of electronic banking including: consumers' perception of a standard and consistence service, the time saving feature of electronic banking, and the absence of personal interactions, have been empirically found to influence consumers' use of electronic banking (Polatoglu and Ekin, 2001; Karjaluoto, Mattila and Pento, 2002). Thus the following relationship is hypothesised:

Well developed service product characteristics positively impact consumers' positive choice of electronic banking.

\subsubsection{Individual Factors}

The electronic banking literature supports that individual factors such as knowledge (Sathye, 1999; Polatoglu and Ekin, 2001), consumer resources, such as money and information reception and processing capabilities (Karjaluoto, Mattila and Pento, 2002; Gerrard and Cunningham, 2003), and lifestyle (Polatoglu and Ekin, 2001) have an impact on consumers' adoption of electric banking. Knowledge refers to the consumers' awareness of each type of electronic banking channel in the 
marketplace, their awareness of the benefits associated with electronic banking, and their knowledge of how to use electronic banking. The consumer resource money refers to the accessibility of a Personal Computer (PC) and the internet. The information processing and processing capabilities resource is concerned with consumers' computer proficiency, aptitude of internet, and the comprehensibility of electronic banking. Lifestyle refers to the social life in consumers banking patterns, such as the consumers' value the independence of the electronic banking process, or values the personal interactions associated with the non-electronic banking process.

Consumers' knowledge of electronic banking plays an important role in their use of electronic banking. Colgate, Nguyen and Lee (2003) stated that when consumers made decisions for different alternatives in the marketplace, the awareness of the existing alternatives was a determinant for consumers to stay with their current banking provider. In the context of electronic banking, Sathye (1999) and Polatoglu and Ekin (2001) empirically supported the idea that consumer knowledge had an affect on electronic banking adoption. Sathye (1999) found that the lack of awareness about electronic banking and its benefits, including the perception of it being non-user friendly contribute to the nonadoption of electronic banking. Furthermore, Polatoglu and Ekin (2001) stated that the more knowledge and skills a consumer possessed about electronic banking, the easier it was for the consumer to utilize electronic banking.

Consumer resources also influence the use of electronic banking. Mols (1998), Sathye (1999) and Karjaluoto, Mattila, and Pento's (2002) studies showed that some consumers lacked access to a personal computer (PC) and this prohibited the adoption of electronic banking. Studies have also shown that consumer resources including computer proficiency influence the consumers' employment of electronic banking. Sathye (1999) demonstrated that consumers described incomprehensibility as a reason for not using electronic banking. Similarly, Karjaluoto, Mattila, and Pento's (2002) empirical results suggested that non-electronic banking users considered electronic banking as difficult to use because they found computers difficult to operate. Gerrard and Cunningham (2003) found that consumers who were non-adopters of electronic banking could be differentiated by their lower computation proficiency and computer skills. Thus the following relationship is hypothesised:

Individual factors are positively related to consumers' positive choice of electronic banking.

\section{Methodology, Theoretical Model and Data}

\subsection{Qualitative Choice Model of Electronic Banking}

The theoretical model is based on the consumer decision making behavior and qualitative choice model. Understanding how people make choices is important for the design of public policies, marketing strategies, product designs, and business investment decisions. Recent advances in theory 
and empirical methods have resulted in an improvement in understanding human choice behavior and the ability to analyse and predict choice behavior.

Models for determining the choice of discrete alternative activities are known as qualitative choice models. A qualitative choice situation is defined as one in which a decision-maker faces a choice among a set of alternatives which satisfy the following criteria:

1. The number of alternatives in the set is finite;

2. The alternatives are mutually exclusive; that is, the person's choosing one alternative in the set necessarily implies that the person does not choose another alternative; and

3. The set of alternatives is exhaustive: that is, all possible alternatives are included, and so the person necessarily chooses one alternative from the set.

Any choice situation in which the decision or choice is represented by a continuous variable is not a qualitative choice situation.

Qualitative choice models designate a class of models, such as logit and probit, which attempt to relate the probability of making a particular choice to various explanatory factors and calculate the probability that the decision-maker will choose a particular choice or decision from a set of choices or decisions $\left(\mathrm{J}_{\mathrm{n}}\right)$, given data observed by the researcher. This choice probability $\left(\mathrm{P}_{\text {in }}\right)$ depends on the observed characteristics of alternative $i\left(z_{i n}\right)$ compared with all other alternatives $\left(z_{j n}\right.$, for all $j$ in $J_{n}$ and $\mathrm{j} \neq \mathrm{i}$ ) and on the observed characteristics of the decision-maker $\left(\mathrm{s}_{\mathrm{n}}\right)$. The choice probability can be specified as a parametric function of the general form:

$$
P_{\text {in }}=f\left(z_{i n}, z_{j n}, s_{n}, \beta\right)
$$

where $\mathrm{f}$ is the function relating the observed data to the choice probabilities specified up to some vector of parameters, $\beta$. By relating qualitative choice models to utility theory, a clear meaning of the choice probabilities emerges from the derivation of probabilities from utility theory. The utility from each alternative depends on various factors, including the characteristics of the alternative and the characteristics of the decision-maker. By labelling the vector of all relevant characteristics of person $\mathrm{n}$ as $r_{n}$ and the vector of all characteristics of .alternative $i$ chosen by person $n$ as $x_{i n}$, utility is a function of these factors,

$$
\mathrm{U}_{\mathrm{in}}=\mathrm{U}\left(\mathrm{x}_{\mathrm{in}}, \mathrm{r}_{\mathrm{n}}\right)
$$

for all $i$ in $J_{n}$, the set of alternatives.

Based on the theory of utility maximisation, the decision-maker therefore chooses the alternative from which they derive the greatest utility. Their choice can be said to be deterministic and they will choose $i\left(i \in J_{n}\right)$ if $U\left(x_{i n}, r_{n}\right) \geq U\left(x_{j n}, r_{n}\right)$, for $\left(i, j \in J_{n}\right.$ and $\left.j \neq i\right)$. To specify the choice probability in qualitative choice models, $\mathrm{U}\left(\mathrm{x}_{\mathrm{in}}, \mathrm{r}_{\mathrm{n}}\right)$ for $\mathrm{i}$ in $\mathrm{J}_{\mathrm{n}}$ is decomposed into two subfunctions, a systematic component that depends only on factors that the researcher observes and another that represents all factors and aspects of utility that are unknown or excluded by the researcher, labelled $\varepsilon_{\text {in }}$. Thus, 


$$
\mathrm{U}_{\text {in }}=\mathrm{U}\left(\mathrm{x}_{\text {in }}, \mathrm{r}_{\mathrm{n}}\right)=\mathrm{V}\left(\mathrm{Z}_{\text {in }}, \mathrm{s}_{\mathrm{n}}\right)+\varepsilon_{\text {in }} .
$$

where $Z_{\text {in }}$ are the observed attributes of alternative $i$ and $s_{n}$ are the observable characteristics of decision-maker $n$.

$$
\begin{array}{llll} 
& P_{\text {in }}=P\left(U_{\text {in }} \geq U_{\text {jn }}\right) & \forall & i, j \in J_{n} \text { and } i \neq j, \\
\text { hence, } \quad & P_{\text {in }}=P\left(V_{\text {in }}-V_{\text {jn }} \geq \varepsilon_{\text {jn }}-\varepsilon_{\text {in }}\right) & \forall & i, j \in J_{n} \text { and } i \neq j .
\end{array}
$$

Qualitative choice models are used to predict probabilities of choices being made and they attempt to relate the probability of making a particular choice to various explanatory factors (Sellar, Chavas and Stoll, 1982).

Therefore the choice probabilities can be expressed as:

$$
\begin{aligned}
& \mathrm{P}_{\text {in }}=\mathrm{e}^{\mu V \mathrm{in}} / \Sigma_{\mathrm{j} \in \mathrm{Jn}} \mathrm{e}^{\mu V \mathrm{jn}} \forall \mathrm{i}, \mathrm{j} \in \mathrm{J}_{\mathrm{n}}, \mu=\text { positive scale parameter, ie. } \mu>0 . \\
\text { or, } \quad & \mathrm{P}_{\mathrm{in}}=1 /\left(1+\mathrm{e}^{-\mu[\operatorname{Vin}-\mathrm{Vjn}]}\right)
\end{aligned}
$$

Under relatively general conditions, the maximum likelihood estimator is consistent, asymptotically efficient and asymptotically normal.

For example, consumers who are considering electronic banking are faced with a simple binary choice situation; to be an electronic banking user, or not to be an electronic banking user. The consumer's utility associated with electronic banking is denoted as $U_{1 n}$ and the utility associated with nonelectronic banking denoted as $\mathrm{U}_{0 \mathrm{n}}$, which is represented as:

$$
\mathrm{U}_{\text {in }}=\mathrm{V}_{\text {in }}+\varepsilon_{\text {in }} \quad \forall \quad \mathrm{i} \in \mathrm{J}_{\mathrm{n}} \text { and } \mathrm{J}_{\mathrm{n}}=\{0,1\}
$$

The consumer will choose to be an electronic banking user if $\mathrm{U}_{1 \mathrm{n}}>\mathrm{U}_{0 \mathrm{n}}$ and the utility of each choice depends on the vector of observable attributes of the choices and the vector of observable consumer characteristics, summarised as $V_{\text {in }}$. All unobservable and excluded attributes and consumer characteristics are represented by the error term, $\varepsilon_{\text {in }}$, that is assumed to be independently and identically Gumbel-distributed. The choice probability of $U_{1 n}>U_{0 n}$ is given as $P_{1 n}=\operatorname{Pr}_{n}\left(U_{1 n}>U_{0 n}\right)=$ $1 /\left(1+\mathrm{e}^{-\mu[\mathrm{V} 1 \mathrm{n}-\mathrm{V} 0 \mathrm{n}]}\right)$, where $\mu>0$. In an electronic banking decision, the vector of observable attributes of the choices and the vector of observable consumer characteristics are represented in parametric functional form. If the random term is assumed to have a logistic distribution, then the above represents the standard binary logit model. However, if we assume that the random term is normally distributed, then the model becomes the binary probit model (Ben-Akiva and Lerman, 1985; Greene, 1990; Maddala, 1993).

The decision to use electronic banking is hypothesised to be a function of the six variables (measured on a 5-point Likert-type scale) and demographic characteristics. The variables include service quality 
dimensions, perceived risk factors, user input factors, price factors, service product characteristics, and individual factors. The demographic variables include age, gender, marital status, ethnic background, educational qualification, employment, income, and area of residence. The logit model will be used in this analysis because of convenience as the differences between the two models are slight (Maddala, 1993). The model will be estimated by the maximum likelihood method used in the LIMDEP software. The proposed empirical model can be written under the general form:

EBANKING $=$ f (SQ, PR, UIF, PI, SP, IN, YOUNG, OLD, GEN, MAR, HIGHSCH, EURO, MAORI, RURAL, HIGH, LOW, BLUE, WHITE, CASUAL, $\varepsilon$ )

Where:

EBANKING $=1$ if the respondent is an electronic banking user; 0 otherwise

\begin{tabular}{|c|c|}
\hline $\operatorname{SQ}(+)=$ & Service quality dimensions \\
\hline $\operatorname{PR}(-)=$ & Perceived risk factors \\
\hline $\mathrm{UIF}(+)=$ & User input factors \\
\hline PI $(-)=$ & Price factors \\
\hline $\mathrm{SP}(+)=$ & Service product characteristics \\
\hline $\mathrm{IN}(+)=$ & Individual factors \\
\hline $\operatorname{OLD}(-)=$ & Age level; 1 if respondent age is above 56 years old; 0 otherwise \\
\hline YOUNG $(+)=$ & Age level; 1 if respondent age is between 18 to 35 years old; 0 otherwise \\
\hline GEN $(+)=$ & Gender; 1 if respondent is a male; 0 otherwise \\
\hline $\operatorname{MAR}(+)=$ & Marital status; 1 if respondent is married; 0 otherwise \\
\hline HIGHSCH (-) = & Education level; 1 if respondent completed high school; 0 otherwise \\
\hline EURO $(+)=$ & $\begin{array}{l}\text { Ethnic group level; } 1 \text { if respondent ethic group is New Zealand European; } 0 \\
\text { otherwise }\end{array}$ \\
\hline $\operatorname{MAORI}(+)=$ & Ethnic group level; 1 if respondent ethic group is Maori; 0 otherwise \\
\hline RURAL $(+)=$ & Residence level; 1 if respondent resides in rural area; 0 otherwise \\
\hline $\mathrm{HIGH}(+)=$ & Income level; 1 if respondent income level is above $\$ 40,000 ; 0$ otherwise \\
\hline LOW $(+)=$ & Income level; 1 if respondent income level is below $\$ 19,999 ; 0$ otherwise \\
\hline $\operatorname{BLUE}(+)=$ & Employment level; 1 if respondent is a blue-collar worker; 0 otherwise \\
\hline WHITE $(+)=$ & Employment level; 1 if respondent is a white-collar worker; 0 otherwise \\
\hline CASUAL $(+)=$ & $\begin{array}{l}\text { Employment level; } 1 \text { if respondent is causal worker (unemployed, students } \\
\text { and house persons; } 0 \text { otherwise }\end{array}$ \\
\hline$\varepsilon=$ & Error term \\
\hline
\end{tabular}

The discrete dependent variable, EBANKING, measures whether an individual is an electronic banking or non-electronic banking user. The dependent variable is based on the question asked in the mail survey: “Are you an electronic banking user?" Demographic characteristics such as age, gender, marital status, education, ethnic group, area of residence, and income were hypothesised to influence 
the respondent's decision to use electronic banking. For example, Filotto, Tanzi and Saita's (1997) study showed that the adoption rates of ATM were higher among younger users. In addition, Barnett (1998) findings showed that the younger the consumers, the more comfortable they were in using electronic banking. Similarly, Karjaluoto, (2002) demonstrated that electronic banking users were younger than non-electronic banking users. These findings imply that older consumers are less likely to favor electronic banking. As for the impact of marital status on the assessment of electronic banking, Stavins (2001) identified that married consumers were more like to use electronic banking.

Katz and Aspden's (1997) findings showed that males were more likely to use electronic banking than females. Similarly, Karjaluoto (2002) found that electronic banking users were dominated by males. Using the findings from these studies, it can be proposed that male gender positively impacts on the choice of electronic banking. In terms of the consumers' ethnic background in electronic banking, Katz and Aspden (1997) found evidence that consumers' ethnic backgrounds were an influential factor in using electronic banking.

Stavins (2001) identified white-collar consumers as being most likely to use electronic banking. It can be postulated that occupation status (namely white-collar) is positively related to the choice of electronic banking. Al-Ashban and Burney (2001) and Stavins (2001) studies showed that as consumers increased their educational qualification level, their adoption of electronic banking would increase as well.

Chan (1997) established that income was the single most important variable that influenced a consumer's use of a credit card. Empirical findings of income positively influencing adoption of electronic banking can be found in Al-Ashban and Burney's (2001), Stavins's (2001) and Karjaluoto's (2002) studies. For example, Stavins (2001) studied the relationship between consumers' area of residence and the use of electronic banking. The author suggested that consumers who reside in different residence areas have heterogeneous tastes and preferences in relation to electronic banking.

This research seeks to determine which age group has the greatest tendency to use electronic banking since different age groups reflect differences in mix and types of banking services used by the respondents. This research would also like to determine if gender plays a part in differentiating respondents who are electronic banking user and those who are not. It would also like to determine whether more educated respondents would likely be electronic banking users. Lastly, it seeks to determine which income group would be most likely to be electronic banking users. Additionally, income was divided into low (below $\$ 19,000$ ), medium (between $\$ 20,000-\$ 39,000$ ) and high (above $\$ 40,000$ ); age group was divided into young (between 18 to 35 years old), medium (36 to 55 years old) and old (above 56 years old); ethnic group was divided into New Zealand European, Maori, and others (Pacific Islander or Asian); and employment level was divided into blue-collar works, white- 
collar worker, casual worker (including unemployed, students and house persons) and retirees. These are dummy variables and one dummy variable is dropped from each group to avoid the dummy trap problem in the model.

\subsection{Data}

Data for this analysis was obtained through a mail survey sent to 1,960 household in New Zealand. The questionnaire gathered information on consumers' decision to use electronic banking versus nonelectronic banking. The mail survey was designed and implemented according to the Dillman Total Design Method (1978), which has proven to result in improved response rates and data quality. Implementation of the method included a cover letter, a questionnaire and a prepaid reply envelope. A post card reminder was mailed to all participants in the sample 2 weeks after the initial mailing. Following this, another cover letter, questionnaire and prepaid reply envelope were sent to participants in the sample who have not responded. Due to the high response rate, no second mailing was required in this research. The questions were phrased in the form of statements scored on a 5point Likert-type scale, where 1 = "strongly disagree," 3 = "neither disagree nor agree," and $5=$ "strongly agree."

The names and addresses for the mail survey were systematically drawn from the 2003 Christchurch Telephone Book. The sampling procedures were based on Cavana, Delahaye and Sekaran's (2001) recommendation. First, a random number of 8 were chosen from a list of random numbers that were generated using a Microsoft Excel Spreadsheet. Subsequently, from the listings in the 2003 Christchurch Telephone Book, potential participants were selected accordingly. A total of 529 useable surveys were returned from the 1,960 mailed out surveys resulting in a useable response rate of $26.99 \%$.

A profile of sampled respondents is presented in Table I. From the total of 529 useable questionnaires, $72.78 \%$ of the respondents were electronic banking users, while $27.22 \%$ of respondents considered themselves as non-electronic banking users. The sample respondents comprised of $56.33 \%$ females and $43.48 \%$ males, and $63.33 \%$ of the respondents were married at the time of the survey. The majority of the survey respondents were between 36 to 45 years (23.63\%) and 46 to 55 years $(22.68 \%)$ and $38.56 \%$ of the respondents resided in the suburban areas. The main ethnic group among the respondents was European $(88.09 \%)$. The median education level of the respondents was determined to be at the tertiary level and the median annual household income for the sample respondents was between $\$ 20,000$ to $\$ 39,999$.

The distributions of 144 non-electronic banking users are similar to the distributions of the 385 electronic banking users in terms of marital status, gender, ethnic background and area of residence. However, the distributions of age group, occupation, annual income, and educational qualification for the non-electronic banking respondents are different from the electronic banking respondents. The 
non-electronic banking users are older than the electronic banking users, with the median age groups between 66 to 75 years old (23.61\%), 46 to 55 years old (21.53\%), and 56 to 65 years old $(20.14 \%)$. In addition, a higher proportion of retired respondents (39.58\%) dominate the non-electronic banking group when compared with the electronic banking group. The majority of the non-electronic banking users' annual incomes are slightly lower than the electronic banking respondents. The educational qualification levels of non-electronic banking respondents are lower than the electronic banking respondents, with sixth form certificate $(17.36 \%)$ as the major educational qualification in the nonelectronic banking group (see Table I)

\section{Empirical Analysis}

The items used to measure each construct were tested for reliability by using a Cronbach's Alpha value of 0.60 as the cut-off point (see Table II). A value of 0.60 or more indicates satisfactory internal consistency reliability in exploratory studies (see Churchill, 1979). The scores of the items (questions) representing each construct were totalled, and a mean score was calculated for each construct. Using these means, together with the demographic characteristics the logit equation was estimated.

Empirical estimates of the logit model via maximum likelihood assures large sample properties of consistency, efficiency, normality of the parameter estimates and validity of the t-test of significance. The estimated results are presented in Table III. In general, the model fitted the data quite well. The chi-square test strongly rejected the hypothesis of no explanatory power and the model correctly predicted $92 \%$ of the observations. Furthermore, SQ, PR, UIF, OLD, WHITE, CASUAL, HIGHSCH, $\mathrm{HIGH}$, and RURAL are statistically significant and the signs on the parameter estimates support the a priori hypotheses outlined earlier.

The estimated coefficients indicate that service quality dimensions (reliability, assurance and responsiveness) and user input factors (control, enjoyment and intent to use) have a positive impact on consumers' likelihood to use electronic banking. This implies the level of service quality in electronic, the independence and freedom associated with electronic banking and the enjoyment that could be derived from electronic banking will favourably influence consumers' decision in using electronic banking.

Perceived risk factors (financial risk, performance risk, physical risk, social risk and psychological risk) were found as hypothesised, to negatively affect the probability to use electronic banking.

Research tells us a consumer who is risk adverse perceives electronic banking as a financial risk when it is not possible to reverse a mistakenly entered transaction or stopping a payment. Furthermore, the threat of personal information accessed by a third party negatively influences a consumer's likelihood to use electronic banking. This supports the finding of Ho and Ng, 1994 and Lockett and Littler, 1997. 
The demographic variables (age, employment, education, income and residence) were also significant in explaining the respondents' probability in using electronic banking. For example, the negative coefficient of the age group above 56 years showed that senior consumers were less likely to use electronic banking. Senior consumers are more risk adverse and prefer a personal banking relationship to non personal electronic banking. High school respondents may be less likely to use electronic banking due to their low income status. Furthermore, electronic banking transaction could be costly for this age group who primarily work part-time.

As expected, high income respondents were less likely to use electronic banking as they may prefer to deal with the bank staff directly when doing complex transactions and handling large sums of money instead of using electronic banking. The significant and positive coefficient for white-collar employment suggests this employment level has a positive impact on the respondents' probability in using electronic banking. Furthermore, the estimated coefficient CASUAL is also positive and significant implying that a respondent who is either unemployed or a student or a house person has a strong probability in using electronic banking. This may be attributed to a low ownership of motorized transport associated with this group. Gender and married status do not have an impact on a consumer's decision to use electronic banking. In addition, a positive relationship was found between the respondents who reside in a rural area and electronic banking. This relationship may be interpreted as distance, a significant determinant for using electronic banking.

Additional information can be obtained through analysis of the marginal effects calculated as the partial derivatives of the non-linear probability function, evaluated at each variable's sample mean (Greene, 1990). For example, in the case of estimation of the parameter on WHITE (employment level), the probability that the respondent is an electronic banking user, ceteris paribus, is approximately $8.93 \%$ lower than if respondent is not a white collar worker. If the perceived risk is decreased by one unit then the probability of a respondent using electronic banking will increase by $24.31 \%$. A unit increase in user input factor will result in an estimated $15.47 \%$ increase in consumers' probability in using electronic banking. 


\section{Conclusions}

The findings of this research confirm the positive relationship between the service quality and user input factor dimensions and electronic banking, and they are consistent with Sathye's (1999), Polatoglu and Ekin's (2001), Karjaluoto, Mattila and Pento's (2002), Liao and Cheung's (2002) and Gerrard and Cunningham's (2003) findings. The negative relationship between the perceived risk factors and electronic banking also support Ho and Ng's (1994), and Lockett and Littler's (1997) findings.

Furthermore, various relationships between electronic banking and demographic characteristics are identified in this study. For example, the results of this research support Barnett's (1998) and Karjaluoto's (2002) findings that consumers in the older age group are negatively disposed towards to electronic banking. Furthermore, the estimated coefficient "Young" was not significant and contradict our hypothesised sign. This is because the medium age group is the base line on the analysis. Thus the probability that a young respondent will use electronic banking is slightly lower than the medium age group. The positive relationship between consumers in white-collar occupations and electronic banking use is also identified in this study, and it parallels Stavins' (2001) findings. In addition, the findings support Stavins' (2001) results that the consumers' different residence areas have different impacts on electronic banking use.

There is a positive relationship between low income consumers and electronic banking even though it is statistically insignificant. It can be argued that the costs associated with electronic banking are currently more affordable than when electronic banking was first launched. Therefore, even low income consumers are not inhabited in their access to electronic banking, and in fact, it may be a lower-cost channel for these consumers due to reduced travel costs. Chung and Paynter's (2001) suggested that the increased availability of electronic banking and the decreasing costs associated with electronic banking could result in an increase in the utilization of electronic banking. In contrast, high income consumers are less likely to use electronic banking due to security reasons. 


\section{References}

Al-Ashban, A. A. and Burney, M. A. (2001) "Customer Adoption of Tele-Banking Technology: the Case of Saudi Arabia”, The International Journal of Bank Marketing, 19(4/5), pp.191-200.

Avkiran, N. K. (1994) "Developing an Instrument to Measure Customer Service Quality in Branch Banking", The International Journal of Bank Marketing, 12(6), pp. 10-19

Barnett, C. (1998) "Virtual Communities and Financial Service: On-Line Business Potentials and Strategies Choice", The International Journal of Bank Marketing, 16(4), pp.161-169.

Bateson, J. E. G. (1985) “Self-Service Consumer: An Exploratory Study”, Journal of Retailing, 61(3), pp. 49-76.

Ben-Akiva, M., and Lerman, S. R. (1985), Discrete Choice Analysis: Theory and Application to Travel Demand, MIT Press, Cambridge, Massachusetts.

Block, C., and Roering, K. J. (1976), Essentials of Consumer Behaviour: Based on Engel, Kollat, and Blackwell's Consumer Behaviour, The Dryden Press, Hinsdale, Illinois.

Byers, R. E., and Lederer, P. L. (2001) "Retail Banking Service Strategy: A Model of Traditional, Electronic, and Mixed Distribution Choices", Journal of Management Information Systems, 18(2), pp.133-156.

Cavana, R.Y., Delahaye, B.L., and Sekaran, U. (2001), Applied Business Research: Qualitative and Quantitative Methods, John Wiley and Sons, Australia.

Chan, R. Y. (1997) "Demographic and Attitudinal Differences Between Active and Inactive Credit Cardholders - the Case of Hong Kong", The International Journal of Bank Marketing, 15(4), pp.117.

Chung, W., and Paynter, J. (2001) “An Evaluation of Internet Banking in New Zealand”, Department of Management Science and Information Systems, the University of Auckland, Auckland, New Zealand.

Churchill, G. A. (1979) "A Paradigm for Developing Better Measures of Marketing Constructs", Journal of Marketing Research, 16(1), pp.64-73.

Clow, K. E., Baack, D., and Fofliasso, C. (1998) "Reducing Perceived Risk Through Advertising Service Quality Cues”, Service Marketing Quarterly, 16(2), pp.151-162.

Colgate, M., Nguyen, V., and Lee, C. (2003) "An Analysis of Why New Zealanders Remain with their Service Providers", University of Auckland Business Review, 5(1), pp.57-66.

Daniel, E. (1999) "Provision of Electronic Banking in the UK and the Republic of Ireland", The International Journal of Bank Marketing, 17(2), pp.72-82.

Davidow, W. H. (1986), Marketing High Technology: An Insider's Review, The Free Press, New York, New York.

Dewey, J. (1910). “How We Think.”, Health, New York.

Dillman, D. A. (1978), Mail and Telephone Surveys: the Total Design Method. A Wiley-Interscience Publication, John Wiley and Sons, New York. 
Engel, J. F., Kollat, D. T., Blackwell, R. D. (1973), Consumer Behaviour. Holt, Rinehart and Winston, Inc. 2nd Edition, New York.

Filotto, U., Tanzi, P, M., and Saita, F. (1997), "Customer Needs and Front-Office Technology Adoption", The International Journal of Bank Marketing, 15(1), pp.13.

Gerdes, Geoffrey R., and Walton, J.K. (2002) "The Use of Checks and Other Noncash Payment Instruments in the United States", Federal Reserve Bulletin, pp. 360-370.

Gerrard, P., and Cunningham, J. B. (2003) "The Diffusion of Internet Banking Among Singapore Consumers", International Journal of Bank Marketing, 21(1), pp.16-28.

Giannakoudi, S. (1999) "Internet Banking: the Digital Voyage of Banking and Money in Cyberspace", Information and Communications Technology Law, 8(3), pp.205-243.

Greene, W. H. (1990), Econometric Analysis, Macmillan Publishing Company, New York.

Hendrikse, M., and Christiaanse, E. (2000), "Mobile Commerce: An Exploratory Study Impacts in MobileSservices," PrimaVera Working Paper 2000-25 (28 August 2003) http://primavera.fee.uva.nl/PDFdocs/2000-25.pdf

Ho, S. S. M., and Ng, V. T. F. (1994) “Customers' Risk Perceptions of Electronic Payment System.”, The International Journal of Bank, 12(8), pp.26-39.

Jun M., and Cai, S. (2001) “The Key Determinants of Internet Banking Service Quality: A Content Analysis”, International Journal of Bank Marketing, 19(7), pp. 276-291.

Katz, J., and Aspden, P. (1997), "Motivations for and Barriers to Internet Usage: Results of a National Public Opinion Survey", Internet Research, 7(3), pp.170.

Karjaluoto, H. (2002) "Selection Criteria for a Mode of Bill Payment: Empirical Investigation among Finnish Bank Customers", International Journal of Retail and Distribution Management, 30(6), pp. 331-339.

Karjaluoto, H., Mattila, M., and Pento, T. (2002) "Electronic Banking in Finland: Consumer Beliefs and Reactions to a New Delivery Channel", Journal of Financial Service Marketing, 6(4), pp.346-361.

Levesque, T., and McDougall, G. H. G. (1996) "Determinants of Customer Satisfaction in Retail Banking”, The International Journal of Bank Marketing, 14(7), pp. 12-20.

Li, F. (2002), "Internet Banking: From New Distribution Channel to New Business Models", International Journal of Business Performance Management, 4(2-4), pp.136-160.

Liao, Z., and Cheung, M. T. (2002) "Internet-Based E-Banking and Consumer Attitudes: An Empirical Study", Information and Management, No. 39, pp. 283-295.

Llosa, S., Chandon, J., and Orsingher, C. (1998) “An Empirical Study of SERVQUAL's Dimensionality", The Service Industries Journal, 18 (2), pp. 16-44.

Lockett, A., and Littler, D. (1997) “The Adoption of Direct Banking Services”, Journal of Marketing Management, No. 13, pp. 791-811.

Loundon, D. L., and Bitta, A. J. D. (1993), Consumer Behaviour: Concepts and Applications, McGraw-Hill Irwin, 4th Edition, New York. 
Lovelock, C. H., Vandermerwe, S., and Lewis, B. (1999), Services Marketing: A European Perspective, Prentice Hall, New Edition, London.

Maddala, G. S. (1993), The Econometrics of Panel Data, Elgar, Brookfield, Vermont.

Mantel, B. (2000) "Why Do Consumers Pay Bills Electronically? An Empirical Analysis", Economic Perspectives, 24(4), pp.32-45.

Mitchell, V. W. (1998) “A Role of Consumer Risk Perceptions in Grocery Retailing”, British Food Journal, 100(4), pp. 171.

Mols, N. P. (1999), “The Internet and the Banks' Strategic Distribution Channel Decisions”, The International Journal of Bank Marketing, 17(6), pp.295-300.

Mols, N. P. (1998) “The Internet and Bank’s Strategic Distribution Channel Decisions”, Internet Research, 8(4), pp. 331-337.

Ng, T., and Palmer, E. (1999) "Customer Satisfaction Attributes for Technology-Interface Services", Unpublished Paper, MSIS Department, School of Business and Economics, University of Auckland, Auckland, New Zealand, No.186, ISSN 1171-557X.

Parasuraman, A., Zeithaml, V. A., and Berry, L.L. (1991) "Refinement and Reassessment of the SERVQUAL Scale”, Journal of Retailing, 67 (4), pp. 420-450.

Parasuraman, A., Zeithaml, V. A., and Berry, L.L. (1988) "SERVQUAL: A Multiple-Item Scale for Measuring Consumer Perceptions of Service Quality”, Journal of Retailing, 64(1), pp. 12-41.

Parasuraman, A., Zeithaml, V. A., and Berry, L. L. (1985) “A Conceptual Model of Service Quality and its Implications for Future Research", Journal of Marketing, 49(4), pp.41-50.

Parker, S. (1999), "Virtually Seamless Style of Banking Leadership." The New Zealand Herald. Available (August 10, 2003) http://www.nzherald.co.nz/business/businessstorydisplay.cfm? storyID $=2623 \&$ thesection $=$ business $\&$ thesubsection $=\&$ thesecondsubsection

Polatoglu, V. N., and Ekin, S. (2001) "An Empirical Investigation of the Turkish Consumers' Acceptance of Internet Banking Services”, International Journal of Bank Marketing, 19(4), pp. 156-165.

Pyun, C. S., Scruggs, L., and Nam, K. (2002), "Internet Banking in the U.S., Japan and Europe", Multinational Business Review, 10(2), pp.73-81.

Rose, Peter S., and Hudgins, S.C. (2005), Bank Management and Financial Services, McGraw-Hill Irwin, New York.

Sarin, S., Sego, T., and Chanvarasuth, N. (2003) "Strategic Use of Bundling for Reducing Consumers' Perceived Risk Associated with the Purchase of New High-Tech Products", Journal of Marketing Theory and Practice, 11(3), pp. 71-83.

Sathye, M. (1999) "Adoption of Internet Banking by Australian Consumers: An Empirical Investigation", The International Journal of Bank Marketing, 17(7), pp. 324-334.

Sellar, C., Chavas, J. P. and Stoll, J. R. (1982) "Specification of the Logit Model: the Case of Valuation of Nonmarket Goods", Natural Resources Working Paper Series, TA-18178. Natural Resources Workgroup. Department of Agricultural Economics, Texas A\&M University. 
Stavins, J. (2001) "Effect of Consumer Characteristics on the Use of Payment Instruments", New England Economic Review, No. 3, pp. 19-31.

Sureshchandar, G. S., Rajendran, C., and Kamalanabhan, T. J. (2001) "Customer Perceptions of Service Quality: A Critique”, Total Quality Management, 12(1), pp. 111-125.

Taylor, K. (2002). "Bank Customers Logging On.” The New Zealand Herald. Available (August 10, 2003) http://www.nzherald.co.nz/storydisplay.cfm?thesection=technology\&thesubsection=\& storyID $=1291883$

Thornton, J., and White, L. (2001) "Customer Orientations and Usage of Financial Distribution Channels”, The Journal of Service Marketing, 15(3), pp.168-185.

Wallis Report. (1997) “The Financial System Inquiry Final Report” (Chairman: Mr Stan Wallis), AGPS, Canberra, Australia.

Zeithaml, V, A. (1981), "How Consumer Evaluation Process Differ Between Goods and Services", in Donnelly, J. H., and George, W, R. (Ed), Marketing of Service, Proceedings Series of the American Marketing Association.

Zeithaml, V, A., and Bitner, M. J. (2003), Services Marketing: Integrating Customer Focus Across the Firm, McGraw-Hill Irwin, 3rd Edition, Boston, Massachusetts.

Zeithaml, V, A., Parasuraman, A., and Berry, L, L. (1990), Delivering Quality Service: Balancing Customer Perceptions and Expectations, The Free Press, New York, New York.

Zhu, F. X., Wymer, W. Jr., and Chen, I. (2002) "IT-Based Services and Service Quality in Consumer Banking", International Journal of Service Industry Management, 13(1), pp. 69-90. 
Figure 1: Consumer Decision-Making Process Model

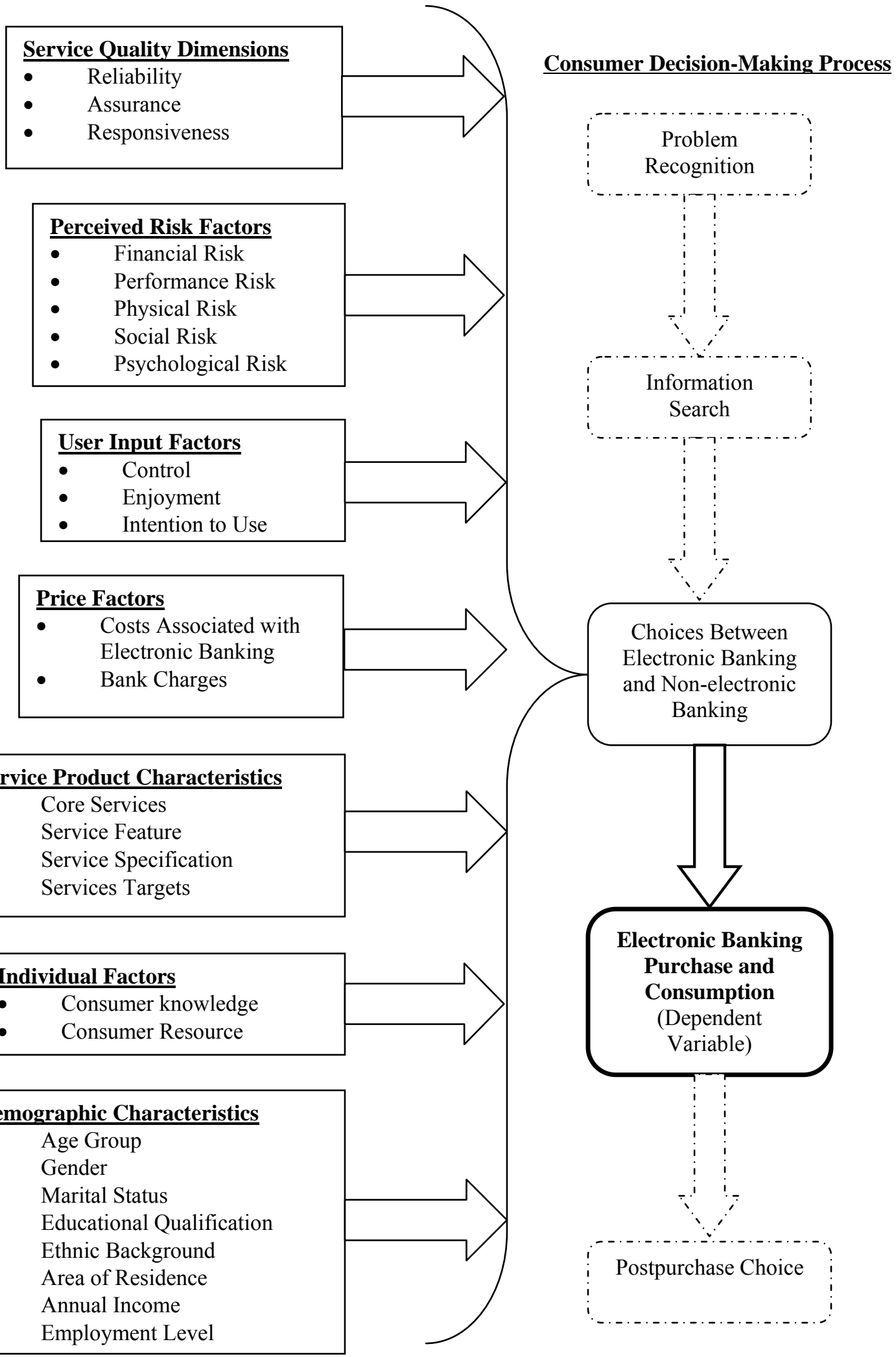


Table 1: Profile of Respondents

\begin{tabular}{|c|c|c|c|c|c|c|c|c|}
\hline \multirow[t]{2}{*}{ Variables } & \multirow[t]{2}{*}{$\mathbf{N}$} & & \multicolumn{2}{|c|}{ Total Respondents } & \multicolumn{2}{|c|}{ Electronic Banking } & \multicolumn{2}{|c|}{$\begin{array}{l}\text { Non-electronic } \\
\text { Banking }\end{array}$} \\
\hline & & & $\begin{array}{l}\text { Frequency } \\
\text { (No. of } \\
\text { respondents } \\
\text { per option) }\end{array}$ & $\%$ & \begin{tabular}{|c|}
$\begin{array}{c}\text { Frequency } \\
\text { (No. of } \\
\text { respondents } \\
\text { per option) }\end{array}$ \\
\end{tabular} & $\%$ & \begin{tabular}{|c|} 
Frequency \\
(No. of \\
respondents \\
per option)
\end{tabular} & $\%$ \\
\hline \multirow[t]{8}{*}{ Age } & \multirow[t]{8}{*}{ Valid } & $18-25$ & 18 & 3.40 & 17 & 4.42 & 1 & 0.69 \\
\hline & & $26-35$ & 83 & 15.69 & 75 & 19.48 & 8 & 5.56 \\
\hline & & $36-45$ & 125 & 23.63 & 109 & 28.31 & 16 & 11.11 \\
\hline & & $46-55$ & 120 & 22.68 & 89 & 23.12 & 31 & 21.53 \\
\hline & & $56-65$ & 85 & 16.07 & 56 & 14.55 & 29 & 20.14 \\
\hline & & $66-75$ & 56 & 10.59 & 22 & 5.71 & 34 & 23.61 \\
\hline & & 75 and over & 42 & 7.94 & 17 & 4.42 & 25 & 17.36 \\
\hline & & Total & 529 & 100.00 & 385 & 100.00 & 144 & 100.00 \\
\hline \multirow[t]{5}{*}{ Gender } & \multirow[t]{3}{*}{ Valid } & Female & 298 & 56.33 & 225 & 58.44 & 73 & 50.69 \\
\hline & & Male & 230 & 43.48 & 159 & 41.30 & 71 & 49.31 \\
\hline & & Total & 528 & 99.81 & 384 & 99.74 & 144 & 100.00 \\
\hline & Missing & & 1 & 0.19 & 1 & 0.26 & 0 & 0.00 \\
\hline & Total & & 529 & 100.00 & 385 & 100.00 & 144 & 100.00 \\
\hline \multirow[t]{8}{*}{ Marital Status } & \multirow[t]{6}{*}{ Valid } & Single/Never married & 76 & 14.37 & 59 & 15.32 & 17 & 11.81 \\
\hline & & Married & 335 & 63.33 & 236 & 61.30 & 99 & 68.75 \\
\hline & & De facto relationship & 44 & 8.32 & 38 & 9.87 & 6 & 4.17 \\
\hline & & Divorced/Separated & 50 & 9.45 & 39 & 10.13 & 11 & 7.64 \\
\hline & & Windowed & 22 & 4.16 & 13 & 3.38 & 9 & 6.25 \\
\hline & & Total & 527 & 99.62 & 385 & 100.00 & 142 & 98.61 \\
\hline & Missing & & 2 & 0.38 & 0 & 0.00 & 2 & 1.39 \\
\hline & Total & & 529 & 100.00 & 385 & 100.00 & 144 & 100.00 \\
\hline \multirow[t]{12}{*}{\begin{tabular}{|l|} 
Educational \\
Qualification
\end{tabular}} & \multirow[t]{10}{*}{ Valid } & Less than fifth form & 54 & 10.21 & 34 & 8.83 & 20 & 13.89 \\
\hline & & Fifth form & 69 & 13.04 & 49 & 12.73 & 20 & 13.89 \\
\hline & & Sixth form & 73 & 13.80 & 48 & 12.47 & 25 & 17.36 \\
\hline & & Seventh form & 36 & 6.81 & 25 & 6.49 & 11 & 7.64 \\
\hline & & Trade qualification & 72 & 13.61 & 52 & 13.51 & 20 & 13.89 \\
\hline & & Diploma & 72 & 13.61 & 54 & 14.03 & 18 & 12.50 \\
\hline & & Bachelors degree & 76 & 14.37 & 66 & 17.14 & 10 & 6.94 \\
\hline & & Postgraduate degree & 44 & 8.32 & 38 & 9.87 & 6 & 4.17 \\
\hline & & Other & 17 & 3.21 & 14 & 3.64 & 3 & 2.08 \\
\hline & & Total & 513 & 96.98 & 380 & 98.70 & 133 & 92.36 \\
\hline & Missing & & 16 & 3.02 & 5 & 1.30 & 11 & 7.64 \\
\hline & Total & & 529 & 100.00 & 385 & 100.00 & 144 & 100.00 \\
\hline \multirow{7}{*}{$\begin{array}{l}\text { Ethnic } \\
\text { background }\end{array}$} & \multirow[t]{6}{*}{ Valid } & NZ European & 466 & 88.09 & 339 & 88.05 & 127 & 88.19 \\
\hline & & NZ Maori & 6 & 1.13 & 5 & 1.30 & 1 & 0.69 \\
\hline & & Pacific Islander & 3 & 0.57 & 2 & 0.52 & 1 & 0.69 \\
\hline & & Asian & 7 & 1.32 & 5 & 1.30 & 2 & 1.39 \\
\hline & & Other & 31 & 5.86 & 27 & 7.01 & 4 & 2.78 \\
\hline & & Total & 513 & 96.98 & 378 & 98.18 & 135 & 93.75 \\
\hline & Missing & & 16 & 3.02 & 7 & 1.82 & 9 & 6.25 \\
\hline
\end{tabular}




\begin{tabular}{|c|c|c|c|c|c|c|c|c|}
\hline & Total & & 529 & 100.00 & 385 & 100.00 & 144 & 100.00 \\
\hline \multirow{6}{*}{$\begin{array}{l}\text { Area of } \\
\text { Residence }\end{array}$} & \multirow[t]{4}{*}{ Valid } & Rural/Farm & 167 & 31.57 & 128 & 33.25 & 39 & 27.08 \\
\hline & & Suburban & 204 & 38.56 & 142 & 36.88 & 62 & 43.06 \\
\hline & & Urban & 150 & 28.36 & 109 & 28.31 & 41 & 28.47 \\
\hline & & \multirow[t]{3}{*}{ Total } & 521 & 98.49 & 379 & 98.44 & 142 & 98.61 \\
\hline & Missing & & 8 & 1.51 & 6 & 1.56 & 2 & 1.39 \\
\hline & Total & & 529 & 100.00 & 385 & 100.00 & 144 & 100.00 \\
\hline \multirow{10}{*}{$\begin{array}{l}\text { Annual } \\
\text { Income }\end{array}$} & \multirow[t]{8}{*}{ Valid } & $\$ 0-\$ 19,999$ & 142 & 26.84 & 95 & 24.68 & 47 & 32.64 \\
\hline & & $\$ 20,000-\$ 39,999$ & 189 & 35.73 & 139 & 36.10 & 50 & 34.72 \\
\hline & & $\$ 40,000-\$ 59,999$ & 93 & 17.58 & 78 & 20.26 & 15 & 10.42 \\
\hline & & $\$ 60,000-\$ 79,999$ & 35 & 6.62 & 27 & 7.01 & 8 & 5.56 \\
\hline & & $\$ 80,000-\$ 99,999$ & 22 & 4.16 & 16 & 4.16 & 6 & 4.17 \\
\hline & & $\$ 100,000-\$ 149,999$ & 20 & 3.78 & 13 & 3.38 & 7 & 4.86 \\
\hline & & $\$ 150,000$ and over & 5 & 0.95 & 4 & 1.04 & 1 & 0.69 \\
\hline & & Total & 506 & 95.65 & 372 & 96.62 & 134 & 93.06 \\
\hline & Missing & & 23 & 4.35 & 13 & 3.38 & 10 & 6.94 \\
\hline & Total & & 529 & 100.00 & 385 & 100.00 & 144 & 100.00 \\
\hline \multirow[t]{14}{*}{ Employment } & \multirow[t]{12}{*}{ Valid } & Clerical & 42 & 7.94 & 38 & 9.87 & 4 & 2.78 \\
\hline & & Sales service & 45 & 8.51 & 39 & 10.13 & 6 & 4.17 \\
\hline & & Professional & 141 & 26.65 & 124 & 32.21 & 17 & 11.81 \\
\hline & & Tradesperson & 29 & 5.48 & 18 & 4.68 & 11 & 7.64 \\
\hline & & Labourer & 13 & 2.46 & 10 & 2.60 & 3 & 2.08 \\
\hline & & Farmer & 33 & 6.24 & 21 & 5.45 & 12 & 8.33 \\
\hline & & Retired & 107 & 20.23 & 50 & 12.99 & 57 & 39.58 \\
\hline & & House person & 35 & 6.62 & 26 & 6.75 & 9 & 6.25 \\
\hline & & Unemployed & 3 & 0.57 & 3 & 0.78 & 1 & 0.69 \\
\hline & & Student & 11 & 2.08 & 10 & 2.60 & 12 & 8.33 \\
\hline & & Other & 51 & 9.64 & 39 & 10.13 & 12 & 8.33 \\
\hline & & Total & 510 & 96.41 & 378 & 98.18 & 132 & 91.67 \\
\hline & Missing & & 19 & 3.59 & 7 & 1.82 & 12 & 8.33 \\
\hline & Total & & 529 & 100.00 & 385 & 100.00 & 144 & 100.00 \\
\hline
\end{tabular}


Table 2: The Reliability Test for the Measures of Electronic Banking

\begin{tabular}{|c|c|c|c|}
\hline & \multirow{2}{*}{\multicolumn{2}{|c|}{ Reliability Test }} \\
\hline & & & \\
\hline \multirow[t]{3}{*}{$\begin{array}{l}\text { Service Quality } \\
\text { Dimensions }\end{array}$} & Reliability & $\begin{array}{l}\text { 1. Transactions through electronic banking are accurate } \\
\text { 2. Transactions through electronic banking are reliable }\end{array}$ & $\begin{array}{l}\text { Cronbach's Alpha } \\
\quad=0.8806\end{array}$ \\
\hline & Assurance & $\begin{array}{l}\text { 3. Electronic banking offers high security } \\
\text { 4. I am familiar with electronic banking } \\
\text { 5. I am comfortable with electronic banking } \\
\text { 6. I have had satisfactory experiences with electronic banking }\end{array}$ & $\begin{array}{l}\text { Cronbach's Alpha } \\
\quad=0.7970\end{array}$ \\
\hline & Responsiveness & $\begin{array}{l}\text { 7. Electronic banking services are faster than in-branch banking } \\
\text { 8. Electronic banking provides easy access for banking transaction }\end{array}$ & $\begin{array}{l}\text { Cronbach's Alpha } \\
\quad=0.6178\end{array}$ \\
\hline \multirow[t]{6}{*}{$\begin{array}{l}\text { Perceived Risk } \\
\text { Factors }\end{array}$} & $\begin{array}{l}\text { Psychological } \\
\text { risk }\end{array}$ & 22. I feel in-branch banking is not consistent with my self-image & N/A \\
\hline & Social risk & 23. I believe my friends will disapprove if I change to in-branch banking & N/A \\
\hline & Time risk & $\begin{array}{l}\text { 24. Travelling to a bank branch involves too much time } \\
\text { 25. In-branch banking involves too much queuing time } \\
\text { 26. Switching from electronic banking to in-branch banking could be } \\
\text { inconvenient for me }\end{array}$ & $\begin{array}{l}\text { Cronbach's Alpha } \\
\quad=0.7341\end{array}$ \\
\hline & Quality risk & 27. In-branch banking is less satisfying than electronic banking & N/A \\
\hline & Financial risk & 28. Going to a bank branch involves travel costs & N/A \\
\hline & Physical risk & $\begin{array}{l}\text { 30. Going to bank branches may result in physical injury due to a } \\
\text { terrorist attack } \\
\text { 31. In-branch banking may result in physical injury due to a robbery }\end{array}$ & $\begin{array}{l}\text { Cronbach's Alpha } \\
\quad=0.8552\end{array}$ \\
\hline \multirow[t]{3}{*}{$\begin{array}{l}\text { User Input } \\
\text { Factors }\end{array}$} & Control & $\begin{array}{l}\text { 17. I like to use electronic banking, because it offers independence } \\
\text { 32. Electronic banking enables me to be fully involved in my banking } \\
\text { transactions } \\
\text { 33. Electronic banking enables me to undertake banking transactions at } \\
\text { my own discretion }\end{array}$ & $\begin{array}{l}\text { Cronbach's Alpha } \\
\quad=0.7163\end{array}$ \\
\hline & Enjoyment & $\begin{array}{l}\text { 34. Electronic banking is enjoyable to use } \\
\text { 35. Electronic banking is user friendly }\end{array}$ & $\begin{array}{c}\text { Cronbach's Alpha } \\
=0.6391\end{array}$ \\
\hline & Intention & $\begin{array}{l}\text { 9. I like to use new methods to conduct banking transactions, e.g. } \\
\text { ATMs, telephone banking or internet banking }\end{array}$ & $\mathrm{N} / \mathrm{A}$ \\
\hline Price Factors & & 16. Electronic banking charges are expensive & N/A \\
\hline $\begin{array}{l}\text { Service Product } \\
\text { Characteristics }\end{array}$ & & $\begin{array}{l}\text { 18. Electronic banking is time saving } \\
\text { 19. Electronic banking is convenient } \\
\text { 20. Customer service in electronic banking has a consistent standard } \\
\text { 21. Electronic banking has a wide variety of services available }\end{array}$ & $\begin{array}{l}\text { Cronbach's Alpha } \\
\quad=0.7913\end{array}$ \\
\hline \multirow[t]{2}{*}{$\begin{array}{l}\text { Individual } \\
\text { Factors }\end{array}$} & $\begin{array}{l}\text { Consumer } \\
\text { resource }\end{array}$ & $\begin{array}{l}\text { 12. I have regular access to a computer } \\
\text { 13. I have regular access to the internet } \\
\text { 14. Electronic banking is easy to use }\end{array}$ & $\begin{array}{l}\text { Cronbach's Alpha } \\
\quad=0.6913\end{array}$ \\
\hline & Lifestyle & $\begin{array}{l}\text { 10. I use electronic banking because my friends use it } \\
\text { 11. The use of electronic banking reflects my social status }\end{array}$ & $\begin{array}{l}\text { Cronbach's Alpha } \\
\quad=0.7185\end{array}$ \\
\hline
\end{tabular}


Table 3: Estimation Results

\begin{tabular}{|c|c|c|c|c|}
\hline \multirow{7}{*}{$\begin{array}{l}\text { Number of Observations: } \\
\text { Initial Log-Likelihood: } \\
\text { Restricted log likelihood } \\
\text { Chi-Squared Statistics: } \\
\text { Degrees of Freedom: } \\
\text { Prob. [ChiSqd > value] } \\
\text { McFadden } \mathrm{R}^{2}\end{array}$} & \multicolumn{2}{|c|}{527} & & \\
\hline & \multicolumn{2}{|c|}{-99.3037} & & \\
\hline & \multicolumn{2}{|c|}{-308.0812} & & \\
\hline & \multicolumn{2}{|c|}{417.5549} & & \\
\hline & \multirow{2}{*}{\multicolumn{2}{|c|}{$\begin{array}{l}19 \\
0.00000\end{array}$}} & & \\
\hline & & & & \\
\hline & \multicolumn{2}{|c|}{0.6777} & & \\
\hline Independent Variable & Coefficient & S.E. & t-ratio & Marginal Effect \\
\hline $\mathrm{SQ}^{* *}$ & 0.9589 & 0.4295 & 2.233 & 0.0664 \\
\hline $\mathrm{PR}^{* *}$ & -3.5082 & 0.4442 & -7.899 & -0.2431 \\
\hline $\mathrm{UIF}^{* *}$ & 2.2332 & 0.3336 & 6.695 & 0.1547 \\
\hline PI & 0.0595 & 0.1716 & 0.347 & 0.0041 \\
\hline SP & -0.1069 & 0.3377 & -0.316 & -0.0074 \\
\hline IN & -0.2003 & 0.3100 & -0.646 & -0.0139 \\
\hline YOUNG & -0.2582 & 0.6410 & -0.403 & -0.0192 \\
\hline OLD* & -0.7996 & 0.5115 & -1.563 & -0.0623 \\
\hline GEN & -0.1911 & 0.4109 & -0.465 & -0.0134 \\
\hline MAR & 0.2143 & 0.4241 & 0.505 & 0.0152 \\
\hline $\mathrm{HIGHSCH}^{* *}$ & -1.1449 & 0.3985 & -2.873 & -0.0866 \\
\hline EURO & 0.4724 & 0.6251 & 0.756 & 0.0382 \\
\hline MAORI & 1.1719 & 1.7379 & 0.674 & 0.0511 \\
\hline RURAL* & 0.6655 & 0.4350 & 1.530 & 0.0420 \\
\hline $\mathrm{HIGH}^{*}$ & -0.6430 & 0.4991 & -1.288 & -0.0492 \\
\hline LOW & 0.3964 & 0.5173 & 0.766 & 0.0255 \\
\hline BLUE & 0.3254 & 0.5455 & 0.596 & 0.0209 \\
\hline WHITE** & 1.4765 & 0.6114 & 2.415 & 0.0893 \\
\hline CASUAL* & 1.4619 & 0.8873 & 1.648 & 0.0638 \\
\hline Constant & 0.1450 & 2.0079 & 0.075 & 0.0104 \\
\hline
\end{tabular}

\section{Prediction classification}

\begin{tabular}{lccc} 
Predicted Outcomes & NEB & EB & Overall $(\mathrm{n}=527)$ \\
\hline \% Correct & 83.22 & 95.31 & 92.03 \\
\hline \% Incorrect & 16.78 & 4.69 & 7.97 \\
\hline
\end{tabular}

Note: $*$ and $* *$ denote statistically significant at 0.10 and 0.05 level of significance respectively. NEB and EB are non-electronic banking and electronic banking respectively. 